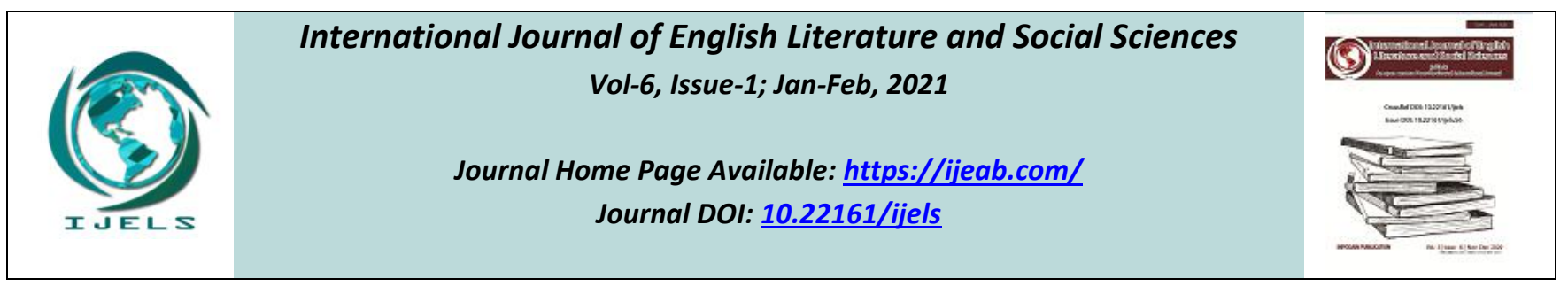

\title{
Reading in the Time of Corona (A Panacea for the Pandemic)
}

\section{Kevin George}

Department of English Literature, KE College, Mannanam, Kerala, India

Received: 28 Nov 2020; Received in revised form: 18 Jan 2021; Accepted: 25 Jan 2021; Available online: 08 Feb 2021

C2021 The Author(s). Published by Infogain Publication. This is an open access article under the CC BY license

(https://creativecommons.org/licenses/by/4.0/).

\begin{abstract}
The stacks of unread books in my cabinet have always disturbed me in one way or the other. They remind me, time and again, that I have fallen back on a promise that I had made to an old friend who encouraged me to take up literature despite my family's predilection for medical-engineering fields. When my relatives and teachers seemed disconcerted and disappointed at my decision, she exhorted me to take the road less travelled (at least, in India). But she made me promise something. I remember the last conversation we had years ago when she said: "Literature/Arts graduates tend to develop apathy towards their areas of interest once they reach 25. I want you to be a life-long learner/reader. Don't give up on reading even when you have managed to land a lucrative job." I found myself transforming into a voracious reader, lucubrating over impenetrable works on philosophy, literature and philology for hours at a stretch. But, somewhere along the way, I developed this hebetude that I had been warned against by my friend. This didn't happen all of a sudden. And I hold responsible not only myself but also the people around me who treat 'the reading type' as mavericks and introverts. I never understood the rationale behind this prejudice. Were they tactfully trying to masquerade their insecurities? I will never know and honestly, I don't care anymore.
\end{abstract}

Keywords-Tsundoku, Covid-19, Dostoevsky, Troglodyte, Nietzsche, Tolstoy

In Kerala, from where I come from, people are more than happy to label the reading-type as nonconformists, Marxists, atheists, anarchists etc. Once you get labelled, you'll find yourself being observed by your colleagues, parents, friends and worst of them all, your students. "Oh! So, you are reading 'The Hermeneutics of Suspicion', aren't you?" asked a relative of mine and it was very obvious that he didn't appreciate it a bit. "Kevin, you are reading too much. You will lose touch with reality" said my uncle when he saw me reading Nietzsche's 'Beyond Good and Evil'. I am sure you don't have to be a clairvoyant to guess what I am driving at. The pandemic (COVID-19), at least for me, was a breath of fresh air. I don't have to deal with these visitors anymore. I don't have to brook gratuitous and bromidic comments anymore. I can live like a troglodyte for the next few months in India (I hail from Kerala). I can finally keep my promise! I finally have a cure for 'Tsundoku' (a Japanese word for the stacks of unread books that are lying around your house).
My stacks include seminal works I've suggested others should read before they die when none of us thought we would die. Deep down, I've always known that I wouldn't read half of these unread books. But the pandemic changed everything, and I am finally coming to grips with what had earlier seemed the sempiternal 'Tsundoku' of my life. I'm embracing Kierkegaard, Sartre, Camus and endless books on existentialist literature and philosophy. I have cooped up in my room savouring classics with a bottle of wine for company. I've also initiated discussions with other bibliophiles on social media (a public sphere) and I've never been this buoyant in my life. We don't have to deal with judgemental people anymore and could have endless discussions, something that had been out of bounds for people like us. This silence is not discomfiting (at least, for me) and it opens up new possibilities for revisiting classics in a different light. I read Shakespeare's 'Coriolanus' and 'Hamlet' a few weeks ago and have almost memorized a few soliloquies, something I thought I could never do. This pandemic is forcing me to address my previously untreated 'Tsundoku' and I know that covid-19 has turned out to be a panacea for all book aficionados. The discussions that 
are happening on LitHub and Goodreads have almost become interminable. They have also come up with lists including "The best books you've never read", "The longest books you should read', "Books you may have missed". In India, academics and scholars from across disciplines have started writing reviews of classics (including modern classics) like 'The Decameron', Camus' 'The Plague' and Hamsun's Nobel winning novel 'Hunger'. There is a surge in interest for books that cause us to reflect and relate. Things that were neglected during the pre-pandemic daily life are coming back to the spotlight. While life has become more comfortable for troglodytes like us, the younger generation seems to have found a new love for books and we are already witnessing the end of narcissistic feeds and stories on Facebook and Instagram. Now, we see more and more youngsters taking up books and attending online lectures (with the tacit consent of their Luddite parents). We have also become more patient with tomes written by Tolstoy and Dostoevsky like 'War and Peace' and 'The Brothers Karamazov'. What had earlier seemed interminable long has become 'readable' for many students (including mine) and adults alike. Our relationship with time has changed as it has slowed down. We have already chosen the timeless. We must have the patience and the tenacity of Whitman's spider until the lockdown comes to an end. And we now have the time to read 'The Iliad'.

On the other hand, I find myself veering away from anything newly published right now. In fact, I find these new texts (both fiction and non-fiction) intolerable to the point that the very idea of having to choose one disconcerts me in an ineffably nauseating (because I am an existentialist) way. But we can't afford to ignore these texts no matter how absurd they seem. For the sake of propriety, I would desist from mentioning the titles of some newly published works. Despite their asinine titles, people (including some academics) have already started extolling their greatness for reasons that are more likely to remain apocryphal for people like me. I am not generalising, of course. But we must also acknowledge the preponderance of bafflingly mediocre works written for the sake of publishing/writing (especially, on social media). In the words of Alain Badiou,

"In passing, one will need to show publicly and dauntlessly that so-called 'social media' have once again demonstrated that they are above all-besides their role in fattening the pockets of billionaires- a place for the propagation of the mental paralysis of braggarts, uncontrolled rumours, the discovery of antediluvian 'novelties', or even fascistic obscurantism" [1].

But, reading the classics, including the seminal works in philology, sociology and philosophy, provides a sense of community that people are desperate for. By reading books that might have been read by millions (in the past and the present), I find myself unwittingly connected to a likeminded/empathetic community. These 1000-page Russian/Greek/Latin tomes have anchored me in my seat.

People from across the globe have started reading classics like Tolstoy's 'War and Peace' twelve-fifteen pages a day. At this pace, they might even finish reading these tomes within three months. I think that's a good sign in the sense that even readers who aren't voracious or as experienced as the recently deceased literary giant Harold Bloom (who used to read an intimidating 400 pages in an hour) have taken up reading of their own volition. My friend who majored in physics recently wrote a review of Dostoyevsky's 'The Idiot' on his blog. Even people from non-literary background have somehow found time to read classics and some of them, to my surprise, have even started endorsing a return to the old liberal-liberal humanist education. This unprecedented response has come from people who had earlier declared themselves as the champions of science and technology. But what will happen when the lockdown eases? How long will this new-found enthusiasm last? Will people get busy again and return to their quotidian routine where they will forever be enveloped in a miasma of intellectual apathy and hebetude? I hope this crisis will prove to be a cure for our Tsundoku.

\section{REFERENCES}

[1] Firmin Badiou, A. (2020). On the Epidemic Situation. Verso Blog, 22(3), 2020. 